Article

\title{
The Role of Agricultural Land Use Pattern Dynamics on Elephant Habitat Depletion and Human-Elephant Conflict in Sri Lanka
}

\author{
J. M. P. N. Anuradha 1,2,*(D), Miho Fujimura ${ }^{3}$, Tsukasa Inaoka ${ }^{3}$ and Norio Sakai $^{1}$ \\ 1 The United Graduate School of Agricultural Sciences, Kagoshima University, Korimoto 1-21-24, \\ Kagoshima 890-0065, Japan; nsakai@agri.kagoshima-u.ac.jp \\ 2 The Department of Agricultural Extension, Faculty of Agriculture, University of Peradeniya, \\ Peradeniya 20400, Sri Lanka \\ 3 The Department of Human Ecology, Faculty of Agriculture, Saga University, 1 Honjo-machi, Saga-shi, \\ Saga 840-8502, Japan; fujimum@cc.saga-u.ac.jp (M.F.); inaoka@cc.saga-u.ac.jp (T.I.) \\ * Correspondence: anuradha119@gmail.com
}

Received: 31 December 2018; Accepted: 14 May 2019; Published: 17 May 2019

\begin{abstract}
The drastic depletion of elephant habitats in the dry zone of Sri Lanka has led to intense human-elephant conflict (HEC) in a region that is home to one of the celebrated agrarian settlements in Asia. Known as the tank villages, these settlements have a long history of human coexistence with elephants and other wild animals. However, the escalating incidence of human-elephant fatalities and crop losses to farmers indicates that the mode of interaction between the tank village inhabitants and the elephants has transformed from coexistence to conflict. Both population and agricultural land use pattern dynamics have contributed to agricultural expansion and loss of elephant habitat in the dry zone of Sri Lanka. However, our knowledge of how the agricultural land use pattern dynamics has contributed to the drastic depletion of elephant range in the dry zone is limited. This research attempted to gain insight into the role of agricultural land use dynamics on elephant habitat depletion and HEC in Sri Lanka through the study of Kuttikulama, a dry zone tank village. The data were collected through focus group discussions, key informant interviews and a cross sectional survey. The study revealed that agricultural land use patterns in traditional dry zone villages have changed in major ways over the last few decades. Such changes included the transition from a shifting-cultivation mode of farming to a fixed sequential mode of farming, the expansion of the per capita cropping area, and the disappearance of communality in agricultural land use patterns. The changes were found to have significantly contributed to a shift in human-elephant interactions from relatively harmonious ones to contentious ones. The study reveals the potential of traditional and alternative cropping and land use systems to minimize human-elephant conflict in Sri Lanka.
\end{abstract}

Keywords: human-elephant conflict; dry zone tank-villages; elephant habitat depletion; agricultural land use pattern dynamics

\section{Introduction}

The traditional tank villages (purana wewu gammana), located in the dry zone of Sri Lanka, are a set of historically celebrated agrarian settlements in Asia. Known for their age-old intricate water conservation and management structures, these agrarian settlements were recently recognized as a Globally Important Agricultural Heritage System (GIAHS) by the Food and Agriculture Organization [1]. As cited in certain historical narratives, the tank village inhabitants have co-existed with the natural environment for many centuries [2-4]. With sustainable land use and environmental resource management practices, the tank village inhabitants contributed significantly to the maintenance of 
an agriculturally and ecologically important ecosystem in an inherently dry region of Sri Lanka [5]. Furthermore, the dry zone tank village systems, owing to their man-made water conservation structures and sustainable agricultural land use patterns, are said to sustain high biodiversity, ranging from the largest mammals on earth to the soil microbes $[1,5]$.

The human-elephant conflict (HEC), which has developed into a wide-spread crisis in the tank villages as well as across the entire dry zone, leads to the presumption that contemporary tank village inhabitants, in contrast to their ancestors, are competing for land and other natural resources with the wild animals. According to Fernando and Pastorini [6], Sri Lanka has the highest level of human-elephant conflict in the world. On average, 250 elephants and 70 humans lose their lives annually due to HEC [7]. Perera [8] reports that farmers in the affected areas lose approximately $6 \%$ of their cumulative annual income due to crop depredation by elephants. Although it is irrational to believe that human-elephant encounters were completely absent throughout the millennia-long civilization in the dry zone, the intense form of the conflict appears to be a recent development that has intensified into a crisis over the last $4-5$ decades [9-11].

Agriculture-induced depletion of elephant habitats in the dry zone, owing to small-farmer agriculture expansion, is among the most critical and on-going drivers behind this conflict. This has serious implications for conservation of the endangered Asian elephants as well as for livelihood security of a large fraction of peasant households dwelling in the dry zone of Sri Lanka [11,12]. It is estimated that over $70 \%$ of the elephant home range is currently outside the natural reserves and sanctuaries where small farmlands dominate the landscape [13].

Apart from the universal underlying causes such as rural population growth, our understanding of more context-specific causes of wildlife habitat depletion in Sri Lanka is minimal. This is particularly true concerning the impact of agricultural land use pattern dynamics. The Asian elephant is a forest-edge species [14]. Thus, change in agricultural land use patterns in the tank-villages, where the forest has been a significant and integral part of the village physical structure, can be thought to have significantly contributed to altering the spatial as well as temporal boundary between human and elephant territories.

In that vein, this research, with reference to a tank village in the dry zone, sought to provide insight into the possible role of agricultural land use pattern dynamics on elephant habitat depletion. Our study attempted to achieve the following specific objectives:

1. To investigate how the agricultural land use patterns have changed in the view of the village inhabitants;

2. To investigate whether, and if so, how the transformation in agricultural land use patterns has contributed to the depletion of elephant habitats and to increased HEC;

3. To investigate whether, and if so, how the current agricultural land use patterns have adapted to overcome the challenges posed by HEC.

\section{Materials and Methods}

We conducted our research in a traditional tank village community called Kuttikulama in the north central dry zone. The southern region of the Kuttikulama village, which overlaps with a prominent elephant corridor that evidently remained intact until few decades back, is now entirely cleared for cash-cropping by the Kuttikulama village dwellers. Table 1 provides a summary on the basic demographics of the study village.

We conducted our study from December 2015 to September 2018. The data were collected through focus group discussions, key informant interviews and a cross sectional survey. The focus group discussions were mainly held with the village elders, who were over 70 years of age and who could recollect the village history as they had experienced and heard from their parents and the grand-parents. Although the number varied in different sessions, a total of 18 village elders participated in the focus group discussions. The cross-sectional survey was conducted with a sample of adult household members representing 150 different households in Kuttikulama (above 50\% of the households in 
Kuttikulama). Since seven of the respondents left the interview halfway through, only 143 completed questionnaires were used in the analysis.

This study mainly used a qualitative research approach to meet its objectives. The study employed quantitative data analytical techniques to substantiate the findings. Chi square test for homogeneity with post-hoc analysis (pair wise comparison using the z-test of two proportions with a Bonferroni correction.) and One-way ANOVA with post-hoc analysis (Tukey-Kramer post hoc test) were used to distinguish the differences between farm household groups (categorized on the basis of location of farm) with different agricultural land use patterns.

Table 1. Demographics of the study area.

\begin{tabular}{cc}
\hline Demographics & Size \\
\hline Area & $521.45 \mathrm{Ha}$ \\
\hline Population & 1027 \\
\hline No. of households & 259 \\
\hline Mean household size & 4 \\
\hline Economically active population & 679 \\
\hline Crop land area (with land use permits) & $155.8 \mathrm{Ha}$ \\
\hline Crop land area (illegal/ encroached) & $234.3 \mathrm{Ha}$ \\
\hline
\end{tabular}

\section{Results and Discussion}

\subsection{A Concise Account of the History of the Tank Villages and Kuttikulama}

The man-made tanks, built to harvest, conserve and manage water for domestic and irrigation purposes, are the most prominent features of the tank villages. The agrarian civilization in the dry zone, which dates back to the 3 rd century $B C$, has been made viable by these water collection and conservation structures [10]. In addition, the man-made tanks increased the viability of an inherently dry region for many aquatic and terrestrial wild-species that play a vital role in the dry zone ecosystem [16-18]. The tanks appear to have sustained the regional elephant population providing water and food on the tank beds.

Each tank village has at least one tank that is held in common by each respective village community. Currently there are around 8500 operational village tanks in the country [19], some of which have been continuously operational for more than two millennia [20] while others were abandoned for various reasons, particularly from the 13th to the 19th century [10,21]. Towards the turn of the 19th century, a great number of abandoned ancient tank villages were rehabilitated and re-inhabited by immigrants from the other parts of Sri Lanka.

Kuttikulama is one of the tank villages that was rehabilitated and resettled early in the 19th century. Although the history of the earliest village settlers, who built the tank (Figure 1), remains unknown, there are a few Kuttikulama elders, who can still recall the recent history of the village starting from the period it was rehabilitated and re-inhabited by 12 of their ancestors. 


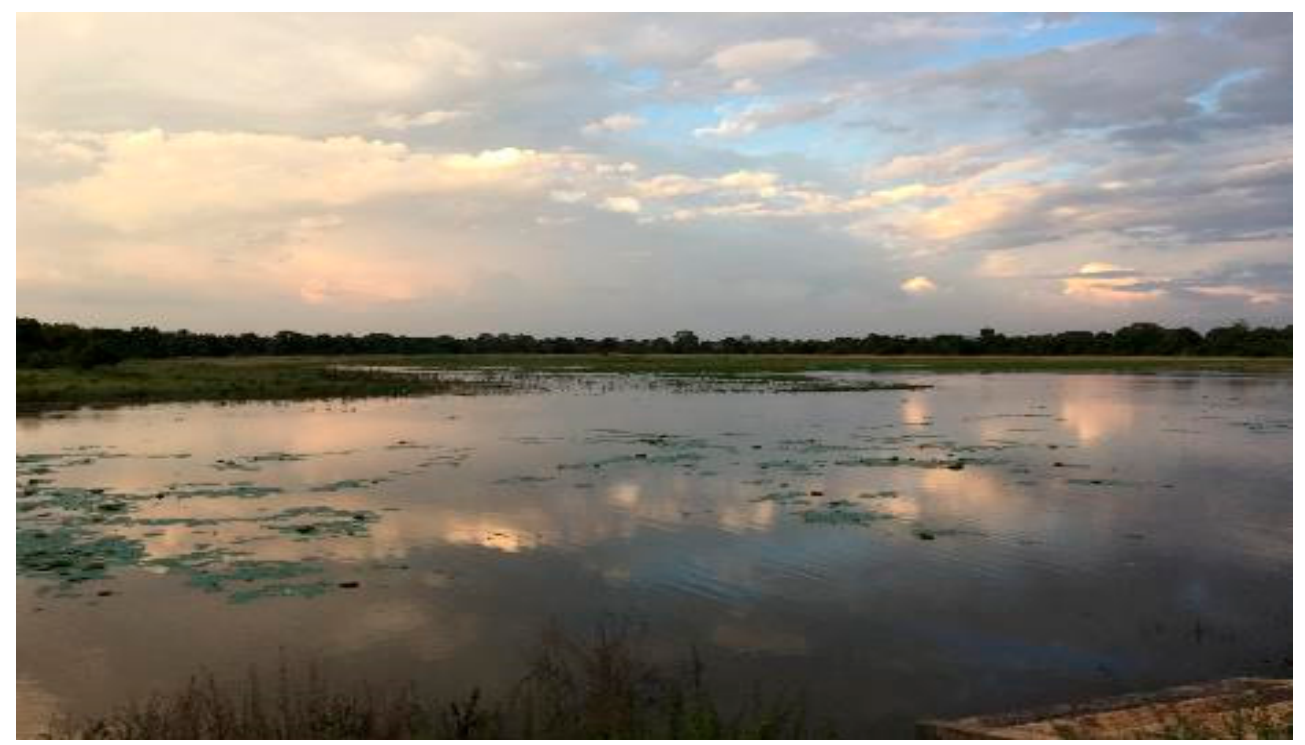

Figure 1. An image of Kuttikulama tank. Note: Water volume of the tank is approx. $1.18 \times 10^{5}$ kilolitre* (Source: [22]).

\subsubsection{Learning to Co-Exist from the Indigenous People}

It is reported that the immigrants, including those who settled Kuttikulama, first temporarily found shelter in villages of the indigenous population (the Vanni people) who had never abandoned the area [23]. This initial contact with the Vanni community imparted the tank-based village traditions and customs to the immigrants. Thus, the settlements initiated by the immigrants also followed the same physical and social structure that had been common and unique to the ancient tank villages. Particularly, the agricultural land use patterns learnt and adopted from the Vanni people helped the immigrants to be an integral part of the legacy of ancient tank village system in which the forest and the wildlife were major components.

The members of the present generation of Kuttikulama are the descendants of the above mentioned 12 ancestral families. Except for two new families that have settled in the recent past, all the other families in Kuttikulma are related to their ancestors as well as to each other by kinship ties along either paternal or maternal lineage. These kinship ties among the community households are a characteristic that still remains distinctively observable in the dry zone tank villages.

\subsubsection{Co-Existing with the Environment}

The earliest settlers of the Kuttikulama village, following the ancient tank village structure [24], located their homestead below and on one side of the bank of the Kuttikulama tank. The land below the Kuttikulama tank was allocated for lowland rice cultivation; whereas the lands situated above the tank, in relatively a higher topography, were designated for cultivation of other annual food crops (chena cropping), such as cereals, oil crops, spices and vegetables. Other than the designated areas for cropping and homestead, the rest of the land surrounding the tank village, particularly the densely forested area in the southern part, was left intact for the wild animals and the forest services (Figure 2). 


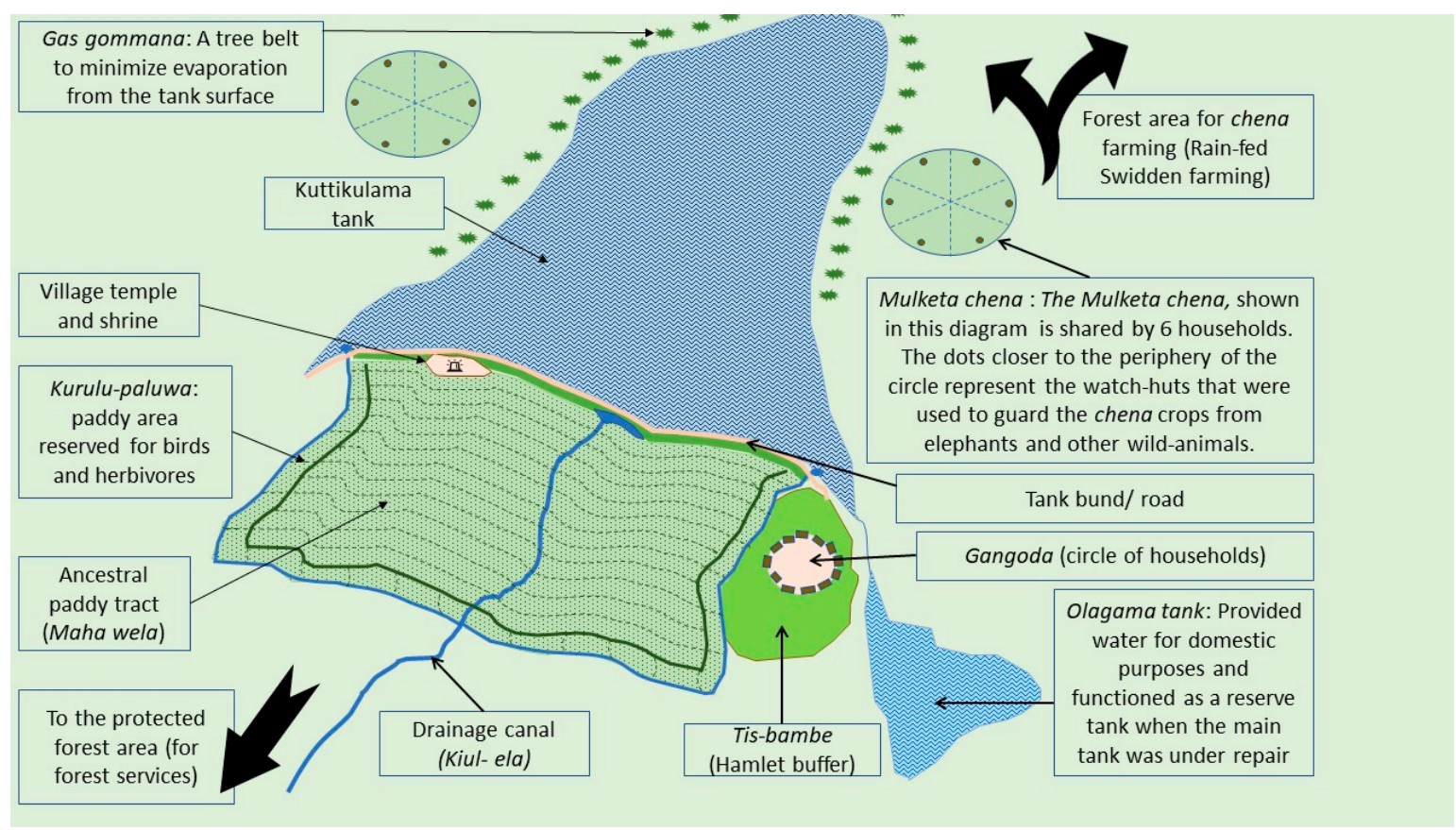

Figure 2. Ancient tank village structure in Kuttikulama (early 19th century). Note: This map is merely a graphical representation of the ancient Kuttikulama village structure; certain components in the map are not proportionately sketched. For instance, Mulketa chena is much smaller than as it appears in the map.

This location of the homestead with close proximity to the village tank provided them with convenient access to water for domestic purposes and a cooler micro-environment for a comfortable life in a dry and windy region. The earliest homestead in Kuttikulma had a circular shape; the houses were located in the periphery with a common home garden in the center. This common center surrounded by households (gangoda) provided the village dwellers, particularly for the women who were alone when the men were off for their farming livelihoods, with an area to assemble in an emergency (i.e., an incidence of wild elephant intrusion). Around the cluster of households, there was a wide strip of land (tis-bambe) cultivated with fruits and coconuts. Although tis-bambe seems to have served as a home garden commonly shared by the village inhabitants, its main role was to protect the village households from wild-animals [5]. Well managed tis-bambe, with an open space under tall perennials, helped the village inhabitants to track the elephants and other wild-animals approaching the homestead from a distance. Furthermore, buffalos and cattle that were ranched in tis-bambe prevented wild animals from trespassing tis-bambe into the homestead [24].

In Kuttikulama, the original rice cultivation area (Maha wela) was divided into twelve 2 acre lots, one for each of the original families. Surrounding this area was a narrow strip of land, also divided into blocks distributed among the households (Figure 2), cultivated with rice but unharvested and left for birds, cattle and wild herbivores. Thus, this rice strip (kurulu paluwa), similar to the buffer zone surrounding the homestead, functioned as a collectively managed crop-fence that guarded the main rice tract from large herbivores. Nevertheless, the main function of kurulu paluwa was to attract birds that were also the enemies of insect pests [25].

Ancient tank dwellers cleared the forest to cultivate chena crops that supported their livelihoods, but after one or two cropping seasons, the crop lands were abandoned for long fallow periods (3-10 years) to allow regeneration of forest vegetation [4]. This secondary forest vegetation provided a lush source of food preferred by large herbivores, such as elephants. Thus, chena cultivation is believed to have enriched habitats for the forest-edge species, such as elephants [26]. In that vein, chena cultivation in Sri Lanka provides a different perspective on shifting cultivation, which has been long accused as a major cause of deforestation in the tropics [27]. 
Forest clearing was also a collective decision resulting in clustered farms rather than scattered and dispersed individual farms [4,28]. In ancient Kuttikulama, there had been two forest encroachment methods in chena farming: "mulketa-hena" (circular-shaped chena) and "iriweli-hena" (linear chena). According to the mulketa-hena method, four to 10 farmers formed into a group to select a suitable forest land for chena cultivation. Then, they cleared the selected forest area in a radius from a pole (mul ketaya) fixed in the center. The resultant was a circle of cleared land divided equally among the members of the farmer group (Figure 2). In the other method: iriweli-hena, farmers in small groups collectively cleared the forest along a linear direction and divided the cleared land among the respective group members.

Group-based land encroachment methods likely also contributed to maintaining a homogeneity in per capita agricultural land sizes (1-2 acres) across the village, as homogeneity itself was a pre-requisite for such group-based farming systems to function. Since the land encroachment in ancient tank villages were based on collective group decisions and strictly observed norms, forest areas deemed critical for wildlife activities were mostly spared. The earlier generations in Kuttikulama never encroached the forest area in the southern region (now designated as a prominent elephant-corridor) other than for hunting and other forest services (i.e., firewood, medicinal plants and occasional timber extraction).

In ancient tank villages, there were also other resource sharing strategies that enabled the tank dwellers to co-exist with the wild animals. One such strategy was to build separate water holes (godawala) or to allocate a separate area of the village tank (Kuluwewa) for the needs of elephants and rest of the wildlife. This reduced human-wildlife conflicts in areas where human activities were abundant [5,25]. Even in Kuttikulama, there are two large water holes, which are located far-off from the main Kuttikulama tank towards the southern border of the village that can be thought to have been built for storing water for roaming elephants and other animals.

In summary, agricultural land use patterns in ancient tank villages appear to have contributed (whether intentionally or not) to preserve the spatial as well as temporal boundary between human and elephant inhabitants. This leads to the presumption that the present-day conflict between the tank dwellers and the wild elephants can be attributed to the depletion of elephant habitats triggered and sustained by the change in agricultural land use patterns (i.e., per capital household cropland extent, fallow length and degree of communality in farming) in interaction with the demographic dynamics.

To investigate the role of agricultural land use pattern dynamics on HEC, we attempted to understand how the traditional agricultural land use patterns in Kuttikulama have changed over time and how these changes have contributed to the depletion of elephant habitats within and surrounding the village.

Since contemporarily chena farming plays the dominant role in the dry zone livelihoods and chena crop lands cover much of the agricultural landscape in Kuttikulama, we concentrated on the impact of chena land use pattern dynamics on depletion of elephant habitats.

\subsection{Change in Chena Land Use Patterns, Depletion of Elephant Habitat and Human-Elephant Conflict in Kuttikulama}

\subsubsection{Structural Changes in Chena Land Use Patterns}

Similar to many traditional agrarian societies across the world, and owing to both demographic and institutional drivers, Kuttikulama village has seen many changes with the passage of time. Among such changes, transformation in chena land use patterns is very distinctive (Figure 3). Although this transformation can be linked to long-term dynamics such as population growth, there is strong evidence that most of this transformation occurred from the early 1970s to the late 1990s. 


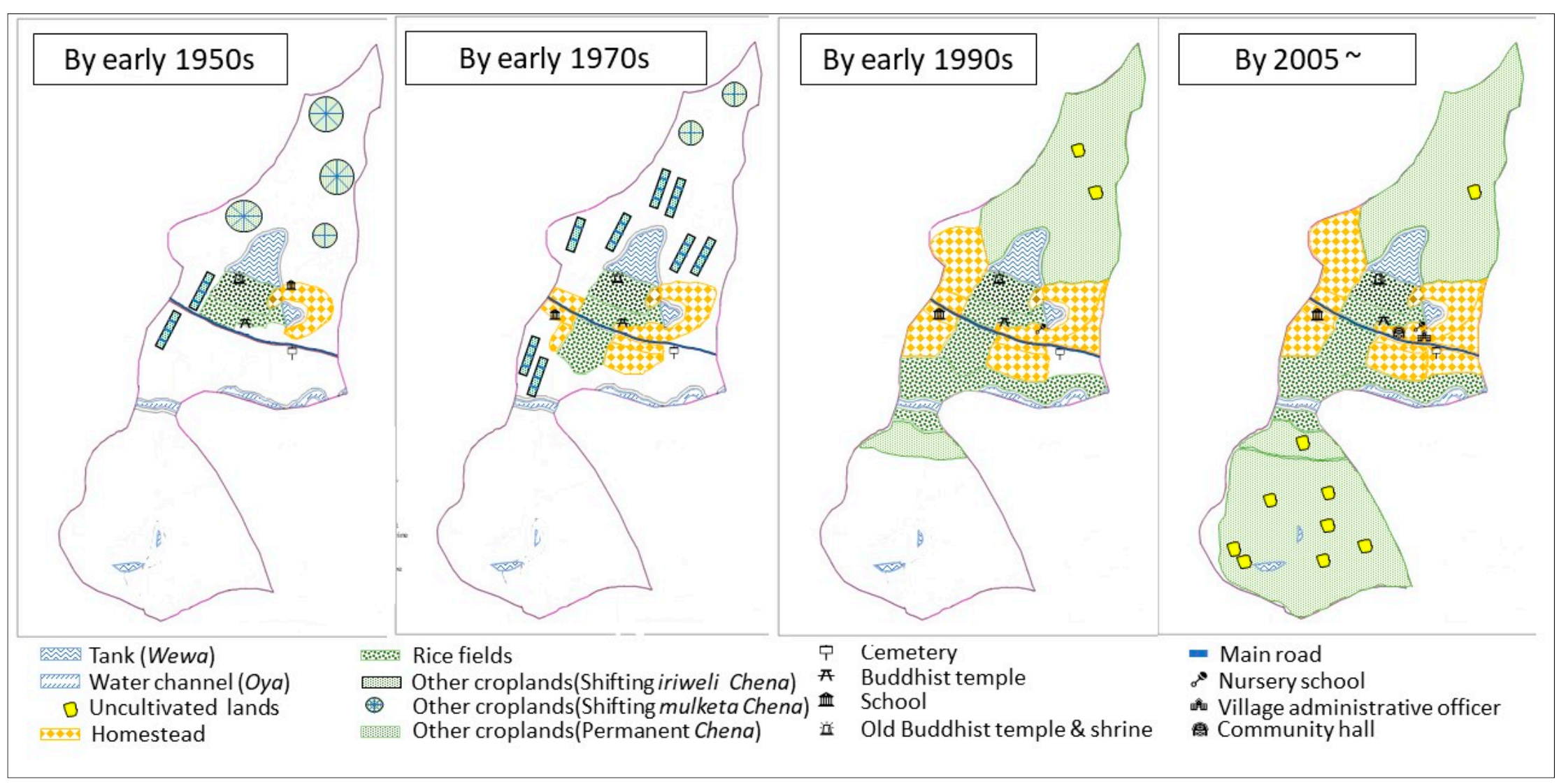

Figure 3. Change in Kuttikulama village structure. 
During the above period, traditional cropping patterns in the dry zone notably changed owing to various government, as well as private sector, initiatives. Promotion of agro-wells (dug-wells to irrigate crops other than rice), land regularization policies, new market opportunities for cash crops, introduction of high yielding crop varieties and other agro-inputs, are among the most influential interventions $[10,29,30]$. Primary drivers of the transformation in chena land use pattern include shifting cultivation being replaced by fixed sequential farming, farmers converting from multi-cropping to mono-cropping of cash crops, expansion of per capita cropping area and disappearance of reciprocal labor and communal efforts in farming [10,29]. It is without any argument that these transformations have been detrimental on the forest cover and the wild animals dwelling in the dry zone. An old farmer leader (72 years old) in Kuttikulama candidly described this transformation:

"In the late 70s, the government introduced agro-wells with lucrative subsidies and encouraged us to cultivate chena crops in fixed places. Issuance of government land permits to lands above the tank, towards the same period, further encouraged the transformation of shifting cultivations into fixed farming. Land permits compelled the farmers to continue farming in lands to which they received permits. Later, some who could not inherit or acquire a crop land in the ancient cropping area (uplands above the tank) started clearing the forest below the paddy tract in the southern region for fixed cropping of chili, onion, pumpkin or other field crops. However, these early encroachments, similar to the croplands above the tank, were limited to one or two acres per household. It is also important to note that land scarcity and various other issues, such as declining prices for crops, compelled some others to limit their cropping activities to home gardens while supplementing their household incomes through odd-jobs, wage-labor or other off-farm income activities. Up until the early 1990s, although forest encroachment for fixed farming continued, forest depletion had not reached a critical level. However, with the introduction of hybrid corn in the early 1990s to this village, farmers cleared the entire remaining forest in the southern part. Moreover, these later encroachments were much bigger in extent. As corn had a good price in the market, even young unemployed or under-employed people were attracted towards farming. It did not take much time for the entire forest to vanish. By the onset of the new millennium, there were no more lands to encroach."

In place of shifting, communally determined circular farm plots or linear farm plots and associated secondary growth during fallow periods, all the farmers in Kuttikulama are now engaged in commercial cropping in fixed lands. Because farm plots are now individually held, wage labor has replaced reciprocal labor, and when individual plots are abandoned or fallowed, they cannot be exploited by wild herbivores because access is blocked by active farm plots.

The most detrimental impact in terms of the diversion of elephant-accessible habitat occurred with the introduction of hybrid corn to the dry zone in the early 1990s. As corn rapidly became a preferred crop, average household cropland extent increased from 1-2 acres to 3-4 acres and forest clearing accelerated. The norms that traditionally restricted exploitative land expansion are no longer pervasive. As many of the focus group discussants pointed out, it took less than 15 years for corn to overtake the remaining forest cover in the southern part of Kuttikulama. Although this forest area in Kuttikulama had been interconnected with the forested parts of the two villages bordering southern Kuttikulama, within the aforementioned period, this entire forest has been almost replaced by corn farmlands of Kuttikulama as well as of the bordering villages. Now the borders of the three villages are the corn farmlands.

\subsubsection{Chena Land Use Pattern Transformation as a Major Cause of HEC}

The above stated major changes in chena farming have brought positive outcomes to the village economies. As the leader of the village farmer organization pointed out, many village households have improved their living standards, particularly owing to corn. However, as the drivers of chena land use transformation resulted in rapid agricultural expansion into wildlife habitat, negative encounters with the elephants have increased. 
As manifested in Kuttikulama, due to HEC, both the human dwellers and the elephants frequently sustain damages. The damage to human dwellers includes heavy crop losses, damage to properties and physical injuries whereas the elephants that intrude into crop farms are made vulnerable to life-threatening attacks by the farmers. Of the 143 households interviewed in Kuttikulama, 85.3\% reported HEC as an issue that exerts a significant risk on their livelihoods. The indigenous medical practitioner specialized in ethno-orthopedic healing in Kuttikulama, who is a respected elder in the village, described his perception on the underlying cause of the HEC:

"The most tangible resultant of the forest cover depletion, owing to change in chena land use pattern, is the intensified conflict between the village farmers and the wild elephants. Our community was distinctively less vulnerable to elephants a few decades back when there was plenty of forest in the southern part of the village. This abundant forest cover provided a rich source of food and space for the elephants, whereas the elephants had far less reasons to depend on the crops cultivated by the humans. However, as the fixed-place farming and lately emerged corn farms have permanently alienated and blocked the elephant corridor, intrusion of elephants into the farmlands has now turned into a very common phenomenon. Rogue elephants visiting us in the homestead is also not a rare phenomenon"

While the majority of households perceive a degree of risk to crops in the face of HEC, farmers using the southern area (SFs), and particularly those expanding into this area most recently (LSFs) perceive themselves to be at much heightened risk (Table 2). Whether SFs see cropping in the southern region where elephant encounters are particularly high as their fate or take it as a rational choice, the only way out to ameliorate the risk depends on their ability and decision to minimize agricultural activities in the southern area.

As shown in Table 2, cultivating chena crops in home gardens seems an alternative that has helped certain farm households to ameliorate the risk from elephants. Chena cropping in home gardens has emerged as a less risky alternative to cropping in the southern region for those households that could not secure a space for cropping in the northern region. However, given the relatively smaller extent of home gardens (Table 2), this alternative cropping system cannot entirely support a household economy without access to another stable farm or off-farm income source. We found that the majority of home garden-farmers (HFs) are involved in multiple livelihood activities related to both agriculture and non-agriculture sectors. Of the agriculture related income sources among HFs, income-oriented rice farming and cattle or buffalo husbandry were found to be prominent. However, many of the HFs had access to off-farm income sources, such as permanent or casual employment in manufacturing or service sector firms. Thus, the household incomes of HFs are comparable to, or even higher than, the incomes earned by SFs or farmers cropping in the northern area (NFs) with much larger extents of crop lands.

We observed that some of the farmers cropping in home gardens and traditional croplands also hold land plots in the southern area that remain abandoned. Behind the reasons for HFs and NFs to still hold plots in the abandoned lands in the southern region, there lies a strong economic motivator. Although legally unaccepted, there is an informal land market that has emerged for croplands in the southern encroached region, where the land transactions are still enforced by social trust as in the past. Thus, the illegal croplands in the southern region, similar to the croplands in the northern region and the home gardens with legally sanctioned titles, have a certain degree of investment value. Meanwhile, we observed that what makes this informal market for vulnerable southern croplands exist is not merely the scarcity of lands, but also the benefits that are inherent to the southern croplands, such as the rich soil fertility. Thus, either cropping or even holding an uncultivated land in the southern region, which seemingly contributes to HEC, cannot be merely the fate of land-scarce farmers, but a reasoned choice. 
Table 2. Livelihood differences among the farm-households based on the location of chena cropping.

\begin{tabular}{|c|c|c|c|c|c|}
\hline & \multicolumn{4}{|c|}{ Observed Values (\% within Each Group) } & \multirow{3}{*}{ Sig. } \\
\hline & \multirow{2}{*}{ NFs $(n=53)$} & \multirow{2}{*}{ HFs $(n=30)$} & \multicolumn{2}{|c|}{ SFs $(n=60)$} & \\
\hline & & & ESFs $(n=31)$ & LSFs $(n=29)$ & \\
\hline $\begin{array}{l}\text { Perceiving HEC as a } \\
\text { significant issue } \\
\text { (No. of respondents) }\end{array}$ & $\begin{array}{c}40 \mathrm{a} \\
(75.5 \%)\end{array}$ & $\begin{array}{c}23 \mathrm{a} \\
(76.7 \%)\end{array}$ & $\begin{array}{c}30 \mathrm{~b} \\
(96.8 \%)\end{array}$ & $\begin{array}{l}29 \mathrm{~b} \\
(100)\end{array}$ & $0.003^{*}$ \\
\hline $\begin{array}{l}\text { Perceiving HEC as a } \\
\text { year-round phenomenon } \\
\text { (No. of respondents) }\end{array}$ & $5 \mathrm{a}^{\#}(9.4 \%)$ & 3 a $(10 \%)$ & $11 \mathrm{~b}(35.5 \%)$ & 28 c $(96.6 \%)$ & $0.000^{*}$ \\
\hline $\begin{array}{l}\text { Crop losses at least once } \\
\text { within the last } 10 \text { years } \\
\text { (No. of farm households) }\end{array}$ & 35 a $(66 \%)$ & 18 a $(60 \%)$ & $27 \mathrm{~b}(87.1 \%)$ & 29 c (100\%) & $0.001^{*}$ \\
\hline $\begin{array}{c}\text { Crop losses in } 2016 \\
\text { (No. of Farm households) }\end{array}$ & $0 \mathrm{a}$ & $0 \mathrm{a}$ & $13 \mathrm{~b}(41.9 \%)$ & $18 \mathrm{~b}(62.1 \%)$ & $0.000^{*}$ \\
\hline $\begin{array}{l}\text { Average paddy land extent } \\
\text { in the paddy tract (acres) }\end{array}$ & $\begin{array}{c}\text { 1.17; SD: } 1.34 \\
n=53\end{array}$ & $\begin{array}{c}1.01 ; \mathrm{SD}: 1.27 \\
n=28\end{array}$ & $\begin{array}{c}\text { 1.10; SD:0.96 } \\
n=30\end{array}$ & $\begin{array}{c}1.12 ; \mathrm{SD}: 1.46 \\
n=29\end{array}$ & $0.967^{+}$ \\
\hline $\begin{array}{l}\text { Average land extent under } \\
\text { chena crops (acres) }\end{array}$ & $\begin{array}{c}2.72 \mathrm{a} \\
\text { SD: } 2.13 \\
n=52\end{array}$ & $\begin{array}{c}0.86 \mathrm{c} ; \\
\text { SD: } 0.96 \\
n=29\end{array}$ & $\begin{array}{c}3.07 \mathrm{a}, \mathrm{b} \\
\mathrm{SD}: 2.65 \\
n=30\end{array}$ & $\begin{array}{c}4.31 \mathrm{~b} \\
\text { SD: } 2.49 \\
n=29\end{array}$ & $0.000^{+}$ \\
\hline Average family size & $\begin{array}{c}4.0 \\
\text { SD: } 1.5\end{array}$ & $\begin{array}{c}4.4 \\
\text { SD: } 1.4\end{array}$ & $\begin{array}{c}4.6 \\
\text { SD: } 1.9\end{array}$ & $\begin{array}{c}4.6 \\
\text { SD: } 1.6\end{array}$ & $0.288^{+}$ \\
\hline $\begin{array}{l}\text { Average annual household } \\
\text { income (Sri Lankan rupee) }\end{array}$ & $\begin{array}{c}398,269 ; \\
\text { SD: } 245,093 \\
n=52\end{array}$ & $\begin{array}{c}503,000 \\
\text { SD: } 203,852 \\
n=29\end{array}$ & $\begin{array}{c}454,720 \\
\text { SD: } 201,664 \\
n=30\end{array}$ & $\begin{array}{c}424,724 \\
\text { SD: } 196,991 \\
n=29\end{array}$ & $0.211^{+}$ \\
\hline $\begin{array}{l}\text { No. households with access } \\
\text { to other income sources }\end{array}$ & $\begin{array}{c}21 \mathrm{a} \\
(39.6 \%)\end{array}$ & $\begin{array}{c}26 \mathrm{c} \\
(86.7 \%)\end{array}$ & $\begin{array}{l}12 \mathrm{a}, \mathrm{b} \\
(38.7 \%)\end{array}$ & $\begin{array}{c}5 \mathrm{~b} \\
(17.2 \%)\end{array}$ & $0.000^{*}$ \\
\hline
\end{tabular}

Note: ${ }^{*}$ Chi square test for homogeneity with post-hoc analysis (pair wise comparison using the z-test of two proportions with a Bonferroni correction.); + One-way ANOVA with post-hoc analysis (Tukey-Kramer post hoc test); Samples were treated for outliers, and hence the adjusted sample sizes are given; $\# \mathrm{a}, \mathrm{b}$ and $\mathrm{c}$ after the observed values indicate similarities among the groups.

\subsubsection{Recent Chena Land Use Adaptations to the Stress from Elephants}

Despite the known risk behind cropping in the southern area of the village, the entire southern area has been under corn for over two decades. Adaptation to this heightened risk of HEC has increased heterogeneity in chena land use patterns.

Throughout the corn cultivation season (October to February), all SFs must engage continuously in overnight crop guarding to protect their crops from elephants. Unlike in the past, crop-guarding is now an individual responsibility as the individual croplands are larger in extent and not always physically interconnected with each other. Because of this extensive, exhausting and non-social activity, SFs prefer to take a break after the corn harvest. However, if they fallow their lands until the next corn cultivation season, the resulting secondary vegetation grown not only adds more cost to subsequent weeding operations, but households depending primarily on income from these croplands cannot afford to keep their croplands fallowed for the rest of the year. The result is cultivation of sesame, a crop unpalatable to elephants. However, for the dry zone, sesame is a risky crop as its market price fluctuates and yield greatly depends on precipitation, which Kuttikulama farmers perceive as unpredictable. Nevertheless, although SFs expect about $50 \%$ crop failure, the planting serves the perhaps more important function of safeguarding their claim to the plot. In contrast to SFs, NFs and HFs cultivate more profitable and less-risky crops, such as pumpkin, water melon or chili.

Cultivation of sesame, between corn plantings may indirectly increase HEC because large portions of the southern area are thus unsuitable for elephant forage and instead they raid the homestead plots. It does not help that these months also coincide with the main migration period for elephant herds, 
with one such migration route passing through what was once the southern forested area. Thus sesame cropping would in fact not be a measure to minimize HEC as recommended by certain previous studies [8].

Finally, the comparatively larger crop extents operated by the SFs, may also be an adaptation against HEC because when the crop is successful the economic return is relatively high. This can help to buffer the farm livelihoods against possible crop losses due to elephant crop raiding. Despite the variability in economic losses due to elephant crop raiding, the annual income between SFs and NFs, whose household income solely depend on farming, do not differ significantly (Table 2).

\subsection{Change in Other Agricultural Land Use Patterns and Impact of Such Changes on HEC}

Compared to chena land use patterns, neither rice farming nor home gardening systems have shown much change in Kuttikulma (Figure 3). However, in response to the population growth, extents of both paddy lands and the homestead have expanded. Although these slow-phase changes have had less impact on elephant habitat depletion, it can be assumed that certain land use changes in homestead and rice field have also contributed to HEC.

One of the influential changes could be the complete disappearance of protective structures that guarded homestead and rice field from elephants and other wildlife. Disappearance of buffer zones around homestead (tis-bambe) and rice field (Kurulu paluwa) is such a distinctive change. Another recent change with an indirect impact on HEC is the depleted prominence of rice as an economic crop. In a way, it can be thought that the weakened role of rice farming in household economies may have indirectly contributed to the promotion of land invasive corn in the lands critical to wildlife activities. However, more comprehensive studies are needed to validate this presumption.

Although home gardening appears as a viable solution to impede elephant habitat depletion, we found that there are reasons that prevent farm households, even with ample unused space in their home gardens, from commercial cropping in home gardens. One such reason is the diffusion of timber crops, particularly teak (Tectona grandis), as a home garden perennial crop within the last two to three decades. Since teak has a high market value, Kuttikulama households cultivate few trees in their home gardens as a security or investment. Thus, these timber crops can be a barrier for the farmers to cultivate chena crops in their home gardens.

\section{Conclusions}

The agricultural land use behavior in ancient tank villages had been structured in such a way that conservation of the ecosystem, co-existence with wildlife, and communal sharing of environmental resources remained cardinal principles of village life. Thus, in a cultural perspective [31], the ancient tank village society had been organized around the mainstreamed belief that humans are subjugated by nature. This cultural character sustained a conservationist agricultural land use pattern in the ancient tank villages, which itself led to minimal conflict between the tank inhabitants and wild elephants. It is important to note that, in compliance with the ideology of "subjugation by nature", ancient dwellers have not just spared the environment to provide space for the elephants, but rather were careful not to disturb the balance of the ecosystem in which the elephants' survival was equally important to that of humans. Supporting this ideology, ancient tank village culture was collectivist rather than individualist. According to Manfredo and Dayer [32], collectivist cultures emphasize sharing wildlife resources, whereas individualist cultures are oriented towards competition over wildlife resources for individual use. Thus, the probability of wildlife facing disturbances from the humans would be less in collectivist cultures compared to that in the individualist cultures. The collectivist, as well as the subjugation-to-nature value orientation, can be distinctively observed in the agricultural land use patterns in ancient Kuttikulama.

As we learnt with reference to Kuttikulama, three major elements in agricultural land use patterns contributed to preservation of elephant habitats and to minimize encounters between the elephants and the human inhabitants in the ancient tank villages: 
1. Social control over expansion of agricultural lands at the expense of elephant habitats: directly enforced by the norms sanctioning conservation of the village forest in the southern region and indirectly through the communally organized land saving strategies, such as communal sharing of land, cluster farming and homogeneity in per capita land endowment.

2. Temporal sharing of land with the elephants and further enrichment of elephant habitats through traditional chena farming system.

3. Land-based physical structures that prevented encounters and promoted harmony between the elephants and the village inhabitants (i.e., tis-bambe and godawela).

In contrast to these historical eco-centric land use patterns, the contemporary agricultural land use patterns in Kuttikulama indicates that the village culture has transformed from collectivist to individualist as well from subjugation to domination in value orientation; hence none of the aforementioned eco-centric elements can be found in the current land use patterns in Kuttikulama. While it is not entirely clear when this ideological shift began, certain external interventions such as land regularization policies, the introduction of agro-wells in the early 1970s and corn in the early 1990s have largely steered this transformation. As we observed in Kuttikulama, the new agricultural land use patterns, which had a short transition period of merely three decades, have demanded the farm households in the tank villages to be more individualistic, competitive and exploitative in acquiring and using land for their agricultural livelihoods. The resultant has been the intense form of the human-elephant conflict that has detrimental consequences to both parties. Moreover, the later land use adaptations to the stress from elephant crop raiding, such as cultivation of crops unpalatable to elephants during the main cultivation seasons, has further aggravated the problem and are likely to bring more detrimental consequences in the future. However, certain agricultural land use alternatives, such as cropping in home gardens while engaging in other non-cropping income sources, have seemingly helped certain village households to minimize the risk from elephants on their livelihoods. We could also find evidence that opting to encroach the elephant habitat for cropping, is not merely the fate of land scarce farm households, but partly a reasoned individual household decision. The significant correlation between the location of the crop land with both the exposure level to elephant crop raiding and involvement in multiple farm or off-farm income sources substantiates the above presumption.

This study highlights the importance of considering context specific socio-cultural reasons underlying elephant habitat depletion in formulating strategies to address the intensifying conflict between the traditional dry zone village communities and elephants in Sri Lanka. The study reveals the potential of ancient and alternative cropping and land use systems in protecting more area for elephant habitats. However, further studies are needed to assess their applicability under the current context and propose modifications to make those systems commercially attractive and socially viable. While encouraging further research and attention of the policy makers on socio-anthropological dimensions of HEC and its root causes, we recommend future studies to expand their focus from land use patterns to all other patterns of using natural resources shared with elephants. We also encourage future studies to work with much larger randomized samples of respondents to increase the generalizability of the findings.

Author Contributions: Conceptualization, J.M.P.N.A., M.F., and T.I.; Methodology, J.M.P.N.A.; Data collection, J.M.P.N.A.; Data analysis, J.M.P.N.A.; Investigation, J.M.P.N.A., M.F., and T.I.; Writing—original draft preparation, J.M.P.N.A.; Writing—review and editing, J.M.P.N.A., M.F., T.I., and N.S.; Supervision, M.F., T.I., and N.S.

Funding: This research received no external funding.

Conflicts of Interest: The authors declare no conflict of interest. 


\section{References}

1. Food and Agriculture Organization of the United Nations. Globally Important Agricultural Heritage Systems: Combining Agricultural Biodiversity, Resilient Ecosystems, Traditional Farming Practices and Cultural Identity; FAO: Rome, Italy, 2018.

2. Mendis, D.L.O. Hydraulic civilization, irrigation ecosystem and the modern state. In Learning from Ancient Hydraulic Civilizations to Combat Climate change: Proceedings of the Regional Pugwash Workshop in Honour of Jayantha Danapala President of the Pugwash Conference on Science and World Affairs 2007-2012; Mendis, D.L.O., Ed.; Pugwash Group: Colombo, Sri Lanka, 2007.

3. Perera, S.A.S. Reverting back to sustainable agricultural practices of ancient hydraulic civilizations of Sri Lanka to combat climate change through patented delta-D technology. In Learning from Ancient Hydraulic Civilizations to Combat Climate Change: Proceedings of the Regional Pugwash Workshop in Honour of Jayantha Danapala President of the Pugwash Conference on Science and World Affairs 2007-2012; Mendis, D.L.O., Ed.; Pugwash Group: Colombo, Sri Lanka, 2007.

4. Perera, J. Change and Settlement: A Portrait of a Sri Lankan Village; Institute for the Study of Languages and Cultures of Asia and Africa: Tokyo, Japan, 1985.

5. Dharmasena, P.B. Small tank heritage and current problems. In Small Tank Settlements in Sri Lanka: Proceedings of a Symposium 2004; Aheeyar, M.M.M., Ed.; HARTI: Colombo, Sri Lanka, 2004.

6. Fernando, P.; Pastorini, J. Range-wide status of Asian elephants. Gajah 2011, 35, 15-20.

7. Fernando, P.; Jayewardene, J.; Prasad, T.; Hendavitharana, W.; Pastorini, J. Current status of Asian elephants in Sri Lanka. Gajah 2011, 35, 93-103.

8. Perera, B.M.A.O. The human-elephant conflict: A review of current status and mitigation methods. Gajah 2009, 30, 41-52.

9. United Nations Development Programme. Sri Lanka Wildlife Conservation Society, Sri Lanka; Equator Initiative Case Study Series: New York, NY, USA, 2012.

10. Panabokke, C.R.; Sakthivadivel, R.; Weerasinghe, A.D. Small Tanks in Sri Lanka: Evolution, Present Status, and Issues; International Water Management Institute: Battaramulla, Sri Lanka, 2002; ISBN 978-92-9090-477-9.

11. Santiapillai, C. Elephant mortality in Sri Lanka. Gajah 1994, 12, 48-54.

12. Fernando, P.; Wikramanayake, E.; Weerakoon, D.; Jayasinghe, L.K.A.; Gunawardene, M.; Janaka, H.K. Perceptions and patterns of human-elephant conflict in old and new settlements in Sri Lanka: Insights for mitigation and management. Biodivers. Conserv. 2005, 14, 2465-2481. [CrossRef]

13. Santiapillai, C.; Wijeyamohan, S.; Bandara, G.; Athurupana, R.; Dissanayake, N.; Read, B. An assessment of the human-elephant conflict in Sri Lanka. Ceylon J. Sci. Biol. Sci. 2010, 39, 21. [CrossRef]

14. Fernando, P. Managing elephants in Sri Lanka: Where we are and where we need to be. Ceylon J. Sci. Biol. Sci. 2015, 44, 1. [CrossRef]

15. Thirappane Divisional Secretariat. Sampath Pathicada [Population Census]; Thirappane Divisional Secretariat: Thirappane, Sri Lanka, 2014.

16. Santiapillai, C.; Wijeyamohan, S. Conservation and the history of human-elephant relations in Sri Lanka. In Rethinking Human-Elephant Relations in South Asia: Conflict, Negotiation, and Coexistence; Locke, P., Buckingham, J., Eds.; Oxford University Press: New Delhi, India, 2016.

17. Geekiyanage, N.; Pushpakumara, D.K.N.G. Ecology of ancient tank cascade systems in island Sri Lanka. J. Mar. Isl. Cult. 2013, 2, 93-101. [CrossRef]

18. Marambe, B.; Pushpakumara, G.; Silva, P. Biodiversity and agrobiodiversity in Sri Lanka: Village tank systems. In The Biodiversity Observation Network in the Asia-Pacific Region: Toward Further Development of Monitoring; Nakano, S., Yahara, T., Nakashizuka, T., Eds.; Springer: Tokyo, Japan, 2012; pp. 403-430. ISBN 978-4-431-54032-8.

19. Dayaratne, S.T. A simulation model for multipurpose multireservoir irrigation system. In Proceedings of the 10th World Water Congress: Water, the World's Most Important Resource, Melbourne, Australia, 2000; International Water Resources Association: Melbourne, Australia, 2000; Available online: https://search.informit.com.au/ documentSummary;dn=515718673908346;res=IELENG;type=pdf (accessed on 16 May 2019).

20. Brohier, R. Ancient Irrigation Works of Ceylon; Govt. Press: Colombo, Sri Lanka, 1935.

21. Zubair, L. Modernization of Sri Lanka's traditional irrigation systems and sustainability. Sci. Technol. Soc. 2005, 10, 161-195. [CrossRef] 
22. Thirappane Divisional Secretariat. Sampath Pathikada [Population Census]; Thirappane Divisional Secretariat: Thirappane, Sri Lanka, 2012.

23. Tennakoon, M.U.A. Traditional Dry Zone Irrigation-Ecosystematic Concepts Revisited and Reconceptualized; SAPSRI: Sri Jayawardenepura Kotte, Sri Lanka, 2015.

24. Dharmasena, P.B. Essential Components of Traditional Village Tank Systems. In Proceedings of the National Conference on Cascade Irrigation Systems for Rural Sustainability, Sri Jayawardenepura Kotte, Sri Lanka, 9 December 2010; Central Environmental Authority: Sri Jayawardenepura Kotte, Sri Lanka, 2010.

25. Bandara, C.M.M. Village tank cascade systems of Sri Lanka, A traditional technology of water and drought management. India Waterportal 2009, 328-336. Available online: https://www.indiawaterportal.org/articles/ village-tank-cascade-systems-sri-lanka-traditional-technology-water-and-drought-management (accessed on 16 May 2019).

26. Pastorini, J.; Janaka, H.K.; Nishantha, H.G.; Prasad, T.; Leimgruber, P.; Fernando, P. A Preliminary study on the impact of changing shifting cultivation practices on dry season forage for Asian elephants in Sri Lanka. Trop. Conserv. Sci. 2013, 6, 770-780. [CrossRef]

27. Angelsen, A. Shifting cultivation and "deforestation": A study from Indonesia. World Dev. 1995, 23, 1713-1729. [CrossRef]

28. Panabokke, C.R. Small Village Tank Systems of Sri Lanka: Their Evolution, Setting, Distribution, and Essential Functions; Hector Kobbekaduwa Agrarian Research and Training Institute: Colombo, Sri Lanka, 2009; ISBN 978-955-612-094-3.

29. Kikuchi, M.; Weligamage, P.; Barker, R.; Samad, M.; Kono, H.; Somaratne, H.M. Agro-Well and Pump Diffusion in the Dry Zone of Sri Lanka: Past Trends, Present Status and Future Prospects; IWMI: Colombo, Sri Lanka, 2003.

30. Shah, T.; Samad, M.; Ariyaratne, R.; Jinapala, K. Ancient small-tank irrigation in Sri Lanka: Continuity and change. Econ. Political Wkl. 2013, 48, 58-65.

31. Milton, K. Environmentalism and Cultural Theory; Routledge: London, UK, 1996.

32. Manfredo, M.J.; Dayer, A.A. Concepts for exploring the social aspects of human-wildlife conflict in a global context. Hum. Dimens. Wildl. 2004, 9, 1-20. [CrossRef] 